(C)Carcinological Society of Japan. doi: 10.18353/crustacea.50.0_131

\title{
Effect of salinity on survival and emigration behaviour during the sea- to-land transition of three terrestrial hermit crab species (Decapoda: Anomura: Coenobitidae) under laboratory conditions
}

Toshihiro Watanabe, Katsuyuki Hamasaki, Shigeki Dan, Shuichi Kitada

\begin{abstract}
Salinity is an important abiotic factor affecting the survival and development of decapod crustacean larvae and juveniles. We investigated the effect of salinity on survival and emigration behaviour during the sea-to-land transition of three terrestrial hermit crab species in the family Coenobitidae (genera Birgus and Coenobita): B. latro, C. brevimanus and C. purpureus. We cultured laboratory-born individuals from megalopae for 63 days in vessels containing both a hard substrate and seawater controlled at four different salinity levels $(25,30,35$ and $40 \mathrm{ppt})$. The overall, survival, shell-carrying and landing activities of the animals were enhanced at lower salinity conditions. Interspecific variability in survival and emigration behaviour was evident: $C$. brevimanus and $C$. purpureus showed relatively high performance even at higher salinity levels when compared with $B$. latro, indicating the differences in hypoosmoregulatory ability among coenobitids. The microhabitats occupied by megalopae and early juveniles of coenobitids could be attributed to the interspecific variability in the osmoregulatory capacity of these animals.
\end{abstract}

Key words: Coconut crab, land hermit crab, early life history, environmental adaptation

\section{Introduction}

Terrestrial hermit crabs in the family Coenobitidae Dana, 1851 comprise land hermit crabs of the genus Coenobita Latreille, 1829 with approximately 17 species as well as the coconut crab Birgus latro (Linnaeus, 1767), the only species in the genus Birgus Leach, 1816 (Hartnoll, 1988; Poupin, 1996; McLaughlin et al., 2010; Rahayu et al., 2016). These crabs are mainly found in subtropical and tropical coastal regions (Hartnoll, 1988). Coenobitid crabs carry gastropod shells, while the shell-carrying behaviour of $B$. latro is an ancestral habit that appears only during the juvenile stage (KadiriJan \& Chauvet, 1998; Greenaway, 2003; Hamasaki et al., 2014a).

Birgus latro is the largest terrestrial arthropod, and it serves as an important local re- source for human consumption (Brown \& Fielder, 1991). However, coconut crab populations have been severely depleted on most inhabited islands because of overharvesting and habitat loss (Amesbury, 1980; Brown \& Fielder, 1991; Drew et al., 2010). Land hermit crabs are also the subject of conservation concerns owing to their exploitation as ornamental animals (Nakasone, 2001; Pavia, 2006).

The larvae of coenobitid crabs hatch on the shore and develop in the sea through several zoeal stages before their metamorphosis into the megalopal stage (Hartnoll, 1988; Nakasone, 2001; Hamasaki et al., 2015a, 2020). After settlement, megalopae acquire empty gastropod shells, migrate onto land and moult to the first crab stage (Reese, 1968; Harvey, 1992; Brodie, 1999; Hamasaki et al., 2014b, 2015b). Therefore, knowledge of the biotic and abiotic 
factors that affect the survival and emigration behaviour of these animals during sea-to-land transition is essential to better understand the recruitment mechanism of coenobitids as well as to develop the artificial propagation technologies of these animals for use by humans.

Salinity is one of the most important abiotic factors known to affect the survival and development of decapod crustacean larvae and juveniles (Anger, 2001, 2003). When animals are exposed to the unfavourable salinity conditions, delayed development, reduced survival, feeding and growth rates, and altered behaviour occur due to enhanced metabolic energy demands for osmoregulation and maintenance (Anger, 2003). Salinity fluctuates temporally and spatially in natural environments where coenobitids may recruit (Tottori et al., 2004; Kawachi \& Ishikawa, 2008; Kawachi et al., 2009; Hamasaki et al., 2018). However, the influence of salinity on survival and emigration behaviour during the sea-to-land transition of coenobitid species remains largely unknown. To date, survival, development, and behaviour such as landing and shell wearing activities have been reported for laboratory-raised megalopae and early juveniles of two coenobitid species: Coenobita rugosus H. Milne-Edwards, 1837 and C. violascens Heller, 1862, under two different salinity levels (24 and $34 \mathrm{ppt}$ ) (Fujikawa et al., 2018).

The present study aimed to investigate the effect of salinity on survival and emigration behaviour during the sea-to-land transition of three terrestrial hermit crab species-B. latro, C. brevimanus Dana, 1852, and C. purpureus Stimpson, 1858-that occur in Japan.

\section{Materials and Methods}

\section{Test animals}

Culture experiments were conducted in a laboratory at the Tokyo University of Marine Science and Technology, Tokyo, from 2014 to 2016. Ovigerous females of three coenobitid species, B. latro, C. brevimanus and C. purpureus, were captured by hand during late June to early July on Hatomajima Island $\left(24^{\circ} 28^{\prime} \mathrm{N}\right.$, $\left.123^{\circ} 49^{\prime} \mathrm{E}\right)$ or Ishigakijima Island $\left(24^{\circ} 23-31^{\prime} \mathrm{N}\right.$, $124^{\circ} 07-18^{\prime} \mathrm{E}$ ) of the Ryukyu Archipelago, Japan. They were transported to the laboratory where the air temperature was controlled at $\sim 27-28^{\circ} \mathrm{C}$, which is equivalent to the summer temperature during the reproductive season of coenobitid crabs in natural habitats.

The crabs were maintained in tanks equipped with simulated land and sea areas (artificial seawater, 34 ppt salinity; Sealife, Marinetech Co. Ltd., Tokyo, Japan) according to the methods of Hamasaki et al. (2009) and Hamasaki (2011). Larval hatching occurred during mid to late July, and newly hatched zoeae from a single female of each species were cultured until metamorphosis to the megalopal stage, according to the methods of Hamasaki et al. (2013).

The larvae metamorphosed into megalopae during the period from late July to early August. The 0-day-old megalopae of each species were housed individually for three days in the wells of 6 six-well cell culture plates, which contained $10 \mathrm{ml}$ artificial seawater (34 ppt salinity, $\sim 28^{\circ} \mathrm{C}$ ) in each well. They were transferred daily into clean culture wells with fresh seawater using a large-mouthed pipette and fed frozen mysid shrimps (Seahorse Ways Co. Ltd., Minamikyushu, Kagoshima, Japan).

All species of the genus Coenobita in Japan are collectively recognised as a Natural Monument Animal to promote their conservation. Coenobita spp., therefore, were collected and cultured under permission (license certificate no. 4-2058) from the Agency for Cultural Affairs, Ministry of Education, Culture, Sports, Science and Technology of Japan. In addition, $B$. latro is listed as 'vulnerable' in the Red Data Book of the Ministry of the Environment of Japan. Therefore, the wild crabs used in the present study were returned to their natural habitats after the experiments were completed. 


\section{Test salinity conditions}

The survival and behaviour of the test animals were examined under the four different salinity levels $(25,30,35$, and $40 \mathrm{ppt})$. The salinity levels of 25, 30 and 35 ppt were adopted for the following reasons. The salinity was recorded at approximately 34-35 ppt in the open ocean around the Ryukyu Archipelago (Hydrographic and Oceanographic Department, 2021), and the salinity fluctuated between approximately 0 and 34 psu in accordance with a tidal cycle in the river mouth of the Nagura Amparu lagoon, Ishigakijima Island (Kawachi \& Ishikawa, 2008; Kawachi et al., 2009). A few mortalities were observed after $24 \mathrm{~h}$ in the coenobitid megalopae when they were abruptly transferred from 34 to $20 \mathrm{ppt}$ salinity, but no mortalities occurred at 24 ppt (Hamasaki et al., unpublished data). Additionally, the highest salinity level of $40 \mathrm{ppt}$ was assumed to occur in intertidal pools under the low tidal condition. Seawater with different salinities was prepared using dechlorinated tap water and artificial seawater salts.

\section{Culture experiments}

The 3-day-old megalopae of each species were housed individually and cultured in transparent plastic containers $(8 \mathrm{~cm}$ wide $\times 20 \mathrm{~cm}$ long $\times 6.5 \mathrm{~cm}$ high) equipped with an inclined simulated land surface ( $350 \mathrm{~g}$ of coral sand; grain diameter $=0.5 \mathrm{~mm}$ ) and designated test seawater $(80 \mathrm{ml})$, as illustrated by Hamasaki et al. (2011). Three sizes of cleaned gastropod shells of Littorina brevicula (Philippi, 1844) (shell length: small, 4.00-4.29 mm; medium, 4.30-4.69 mm, and large, 4.70-4.99 mm) were placed at the bottom of the sea area in each container because juvenile terrestrial hermit crabs prefer larger shells as they increase in size (Hamasaki et al., 2015b). A total of 15 animals of each species were used for each salinity level. The containers were covered with $0.9 \mathrm{~mm}$ mesh-sized plankton netting to prevent the animals from escaping. The test containers were placed in 2-cm-deep water baths $(38 \mathrm{~cm}$ $\times 60 \mathrm{~cm} \times 7.5 \mathrm{~cm}$ ) to maintain similar temperature and humidity among the culture containers. The photoperiod (13 h light: $11 \mathrm{~h}$ dark) and temperature $\left(\sim 28^{\circ} \mathrm{C}\right)$ in the culture room approximated the summer environment.

According to the methods of Hamasaki et al. (2011, 2015b), the cultured animals were observed once daily until 63 days after metamorphosis into the megalopal stage for survival, shell use (carrying or not), wearing-shell type (small, medium or large) and location (seawater or land). After the daily data collection, the seawater in each test container was renewed with seawaters with designated salinity levels. Frozen mysid shrimps and freeze-dried polychaete (Kyorin Co. Ltd., Himeji, Hyogo, Japan) were given to the cultured animals as food in the seawater and on land, respectively. Feeding of freeze-dried polychaete was initiated after the first landing event occurred for each cultured animal.

The air temperature, relative humidity and seawater temperature were recorded every 10 min with data loggers (Hygrochron and

Table 1. Culture conditions (mean \pm standard deviation) of three terrestrial hermit crab species in the genus Birgus and Coenobita during sea-to-land transition. The air temperature (AT), relative humidity (RH), and seawater temperature (SWT) were recorded every $10 \mathrm{~min}$ with data loggers in the containers, and the salinity of the seawater was measured from the containers of each salinity level after the daily data collection.

\begin{tabular}{lccccccc}
\hline \multicolumn{1}{c}{ Species } & AT & RH & SWT & & \multicolumn{2}{c}{ Salinity level (ppt) } \\
\cline { 5 - 8 } & $\left({ }^{\circ} \mathrm{C}\right)$ & $(\%)$ & $\left({ }^{\circ} \mathrm{C}\right)$ & 25 & 30 & 35 & 40 \\
\hline B. latro & $27.9 \pm 0.8$ & $81.8 \pm 4.3$ & $27.4 \pm 0.8$ & $26.1 \pm 1.1$ & $31.0 \pm 1.0$ & $35.9 \pm 1.2$ & $41.3 \pm 1.3$ \\
C. brevimanus & $28.4 \pm 0.8$ & $82.9 \pm 5.0$ & $27.8 \pm 0.8$ & $25.9 \pm 1.1$ & $31.1 \pm 1.2$ & $35.4 \pm 3.2$ & $40.8 \pm 1.0$ \\
C. purpureus & $27.9 \pm 0.4$ & $89.4 \pm 1.7$ & $28.0 \pm 0.4$ & $25.8 \pm 1.5$ & $30.6 \pm 0.9$ & $35.8 \pm 1.1$ & $41.1 \pm 2.5$ \\
\hline
\end{tabular}


Thermochron SL, KN Laboratories Co. Ltd., Osaka, Japan) in the containers during the culture period. These records (mean \pm standard deviation values) are summarised for each species in Table 1 . The seawater salinity measured from the containers of each salinity level after the daily data collection is also summarised for each species in Table 1.

\section{Data analysis}

The daily survival rate of animals was calculated for each salinity level for each species as (number of animals surviving)/(initial number of animals $) \times 100$. Additionally, we considered the following data as behavioural aspects of animals: the daily proportions of (1) animals carrying shells, (2) observed on land, and (3) carrying small, medium or large shells. The proportion of animals was calculated as follows: (number of animals engaged in designated behaviour) / (number of animals surviving for (1) and (2) or number of animals carrying shells for (3)) $\times 100$. Three animals of $B$. latro cultured at $35 \mathrm{ppt}$, one $C$. purpureus cultured at $35 \mathrm{ppt}$ and one C. purpureus cultured at $40 \mathrm{ppt}$ escaped from the culture containers during the experiments; these animals were excluded from the data analyses.

Statistical analyses were performed using $\mathrm{R}$ statistical software (R4.1.1; R Core Team, 2021 ) at a 5\% significance level. We employed a generalised linear model (GLM) with a binomial family using the glm function (logit link) to evaluate the effect of salinity on animal survival, taking into account the interspecific comparison. In the GLM analyses, the final survival rate was the response variable, and the salinity level and species were categorical explanatory variables. A generalised linear mixed-effects model (GLMM) with a binomial family was also performed using the glmer function (logit link) implemented in the lme4 package (Bates et al., 2015) to evaluate the daily behavioural aspects because these data were collected repeatedly in each animal group under the designated salinity level (Zuur et al., 2009). In the GLMM analyses, the daily proportions of animals carrying shells and landing during the experiments were response variables. The salinity level and species were categorical explanatory variables, and the identity of salinity groups was included as a random intercept effect. The GLMM analysis was also employed to evaluate the daily proportion of animals carrying large shells because wearing a gastropod shell is energetically costly for land hermit crabs (Osorno et al., 2005) and thus shell-size preference by test animals may differ among salinity levels.

The statistical significance of the response variables was evaluated with the likelihood ratio test (type II) and Wald chi-square test (type II) for the GLM and GLMM analyses, respectively, using the Anova function implemented in the car package (Fox \& Weisberg, 2011). Additionally, differences in the survival and behavioural traits between the species were tested with Tukey's method using the glht function in the multcomp package (Hothorn et al., 2008).

\section{Results}

The analysis deviance table based on the GLM and GLMM evaluating the effects of salinity and species on survival and behavioural aspects of the animals is summarised in Table 2. The daily proportions of animals surviving, carrying shells and landing as well as those carrying small, medium or large shells are shown for each salinity level for each species in Figs. 1-3 and 4-6, respectively. The predicted values, with $95 \%$ confidence intervals, of the proportions of animals that survived at the end of the experiments and those engaged in designated behaviours were derived from the GLM and GLMM analyses for each salinity level for each species; they are shown in Fig. 7.

The GLM and GLMM analyses detected the significant influences of salinity and species on animal survival and behaviour (Table 2). 
Table 2. Analysis of deviance table by the likelihood ratio test for survival (generalised linear model) and the Wald chi-square test for behaviour (generalised linear mixed-effects model) to evaluate the effects of salinity and species on the proportions of animals that survived at the end of the culture experiments as well as daily proportions of animals carrying shells and landing among surviving animals and those carrying large shells among shell-wearing animals during the culture experiments with three terrestrial hermit crab species.

\begin{tabular}{|c|c|c|c|c|c|}
\hline Response variable & $N$ & Explanatory variable & $\chi^{2}$ value & $d f$ & $P$ value \\
\hline \multirow[t]{2}{*}{ Survival } & 12 & Salinity & 22.34 & 3 & $<0.0001$ \\
\hline & & Species & 137.72 & 2 & $<0.0001$ \\
\hline \multirow[t]{2}{*}{ Carrying shells } & 681 & Salinity & 11.77 & 3 & 0.0082 \\
\hline & & Species & 33.78 & 2 & $<0.0001$ \\
\hline \multirow[t]{2}{*}{ Carrying large shells } & 681 & Salinity & 39.89 & 3 & $<0.0001$ \\
\hline & & Species & 26.23 & 2 & $<0.0001$ \\
\hline \multirow[t]{2}{*}{ Landing } & 681 & Salinity & 71.61 & 3 & $<0.0001$ \\
\hline & & Species & 65.81 & 2 & $<0.0001$ \\
\hline
\end{tabular}

$N$, number of data analysed; $d f$, degree of freedom.

\section{Survival}

$B$. latro showed the lowest survival rates (Figs. 1A-3A), and all animals died at $35 \mathrm{ppt}$ and $40 \mathrm{ppt}$ (Fig. 1A). For the C. brevimanus, mortality occurred only at $40 \mathrm{ppt}$ (Fig. 2A). For the $C$. purpureus, survival rates were high $(>90 \%)$ at $>35$ ppt but lower $(\sim 70 \%)$ at $40 \mathrm{ppt}$ (Fig. 3A). The final survival rate decreased with increasing salinity level in all species, and it was significantly lower in B. latro than in the other species (Fig. 7A).

\section{Shell-carrying behaviour}

The daily proportions of animals carrying shells increased linearly and reached $>80 \%$ at the age of 10 days in all species at all salinity levels except for C. purpureus at $40 \mathrm{ppt}$, in which the proportion carrying shells reached $>80 \%$ at the age of 24 days (Figs. 1B-3B). Thereafter, a large number of animals wore shells, but, for $B$. latro, the proportions carrying shells fluctuated greatly at $35 \mathrm{ppt}$ during the later experimental period (Fig. 1B). The overall proportions of animals carrying shells decreased with increasing salinity level in all species, and they were significantly different between the species (Fig. 7B).

The animals in the experiment occasionally changed shells. In general, animals of early
(A) B. latro: survival

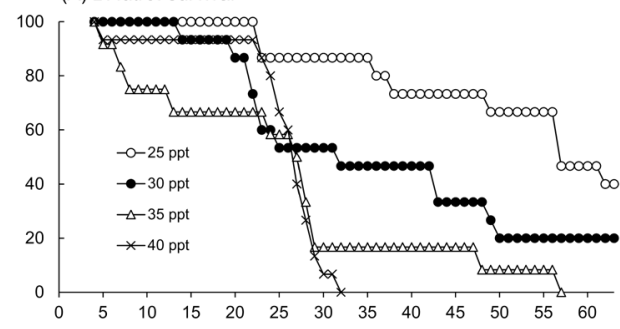

(B) B. latro: carrying shells

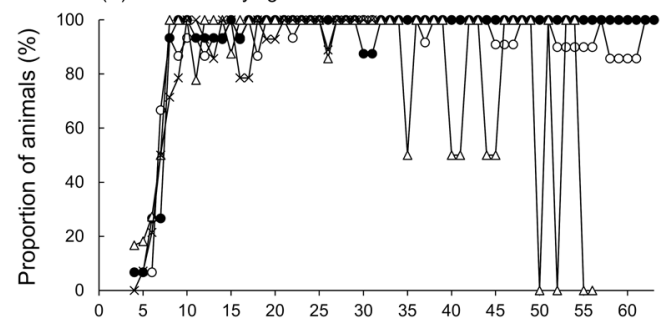

(C) B. latro: landing

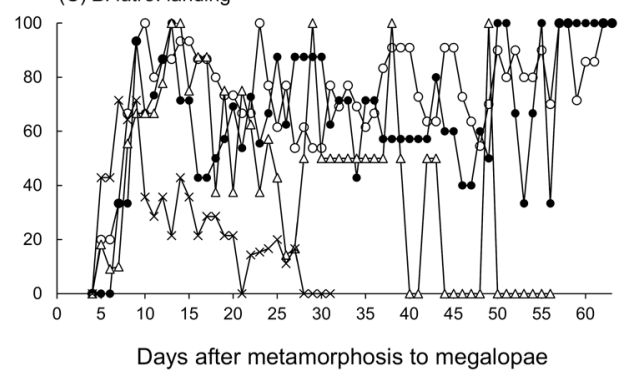

Fig. 1. Changes in the proportions of animals surviving (A), carrying shells (B) and landing (C) during the sea-to-land transition of Birgus latro under four different salinity levels $(25,30,35$ and $40 \mathrm{ppt})$. The culture experiments started with 3-day-old animals. 
(A) C. brevimanus: survival

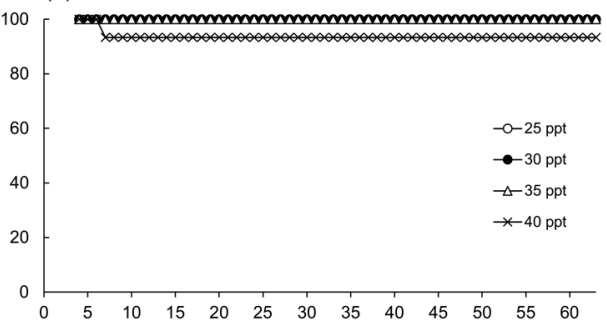

(B) C. brevimanus: carrying shells

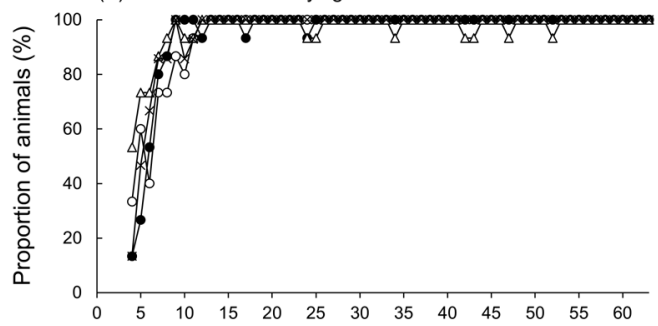

(C) C. brevimanus: landing

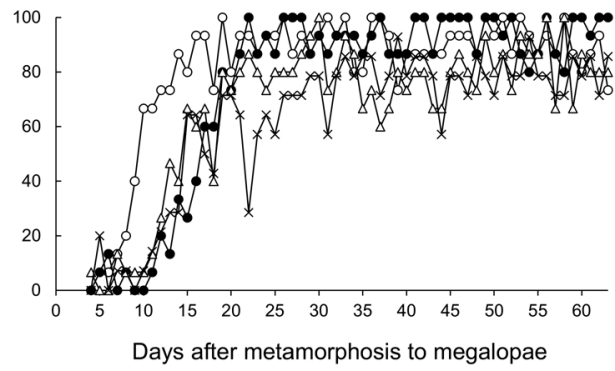

Fig. 2. Changes in the proportions of animals surviving (A), carrying shells (B) and landing (C) during the sea-toland transition of Coenobita brevimanus under four different salinity levels $(25,30,35$ and $40 \mathrm{ppt})$. The culture experiments started with 3-day-old animals.

ages tended to wear medium or large shells in all species (Figs. 4-6), but the proportions of animals carrying these shells decreased during the first landing phase and then re-increased according to age. The overall proportions of animals carrying large shells decreased with increasing salinity level in all species, and they were significantly larger in $C$. purpureus than in the other species (Fig. 7C).

\section{Landing behaviour}

After migrating onto land, all species often moved between land and seawater. For the $B$. latro, the daily proportions of animals landing
(A) C. purpureus: survival

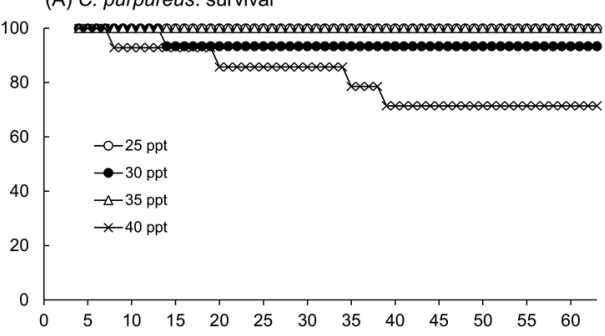

(B) C. purpureus: carrying shells

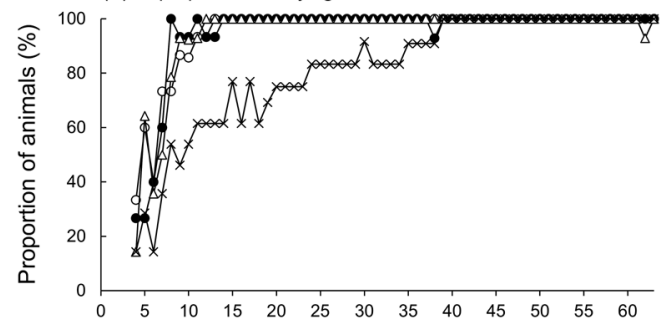

(C) C. purpureus: landing

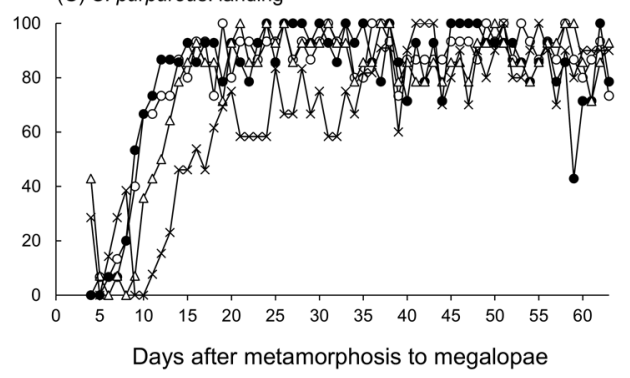

Fig. 3. Changes in the proportions of animals surviving (A), carrying shells (B) and landing (C) during the sea-to-land transition of Coenobita purpureus under four different salinity levels $(25,30,35$ and $40 \mathrm{ppt})$. The culture experiments started with 3-day-old animals.

increased at the age of 10 days (Fig. 1C); afterwards, they fluctuated between approximately $40 \%$ and $100 \%$ at $25-35$ ppt. However, they fluctuated greatly at $35 \mathrm{ppt}$ during the later experimental period and decreased to $0 \%$ after 28 days at $40 \mathrm{ppt}$. The proportions of C. brevimanus and $C$. purpureus landing increased linearly until the ages of 15-20 days (Figs. 2C and $3 \mathrm{C})$, after which they fluctuated between approximately $60 \%$ and $100 \%$, while showing higher values at lower salinity levels. The overall proportions of animals landing decreased with increasing salinity level in all species, and they were significantly lower in 
(A) B. latro: $25 \mathrm{ppt}$

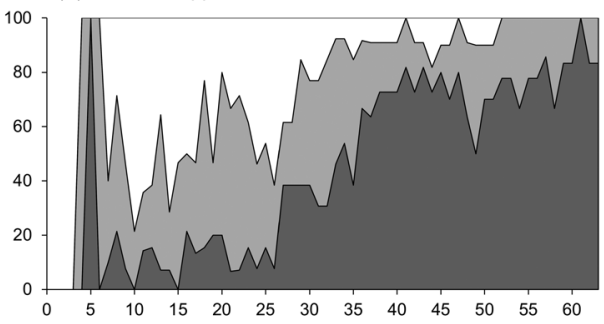

(B) B. latro: $30 \mathrm{ppt}$

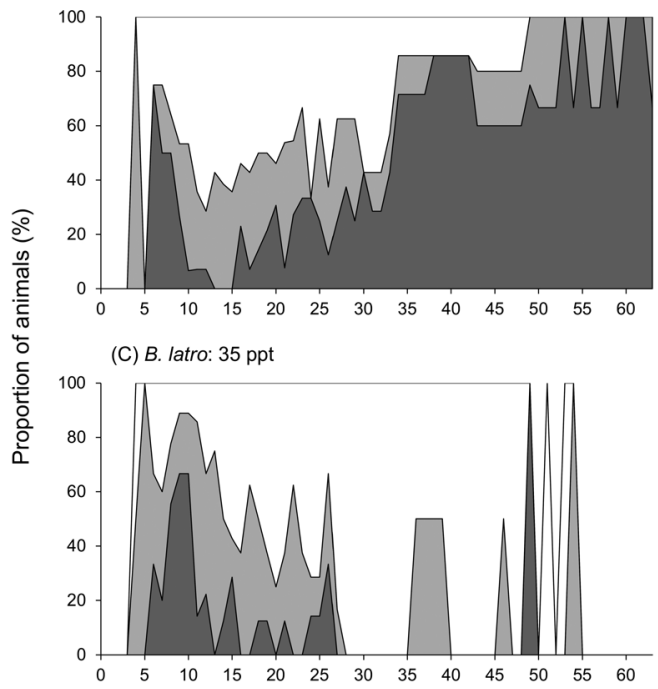

(D) B. latro: $40 \mathrm{ppt}$

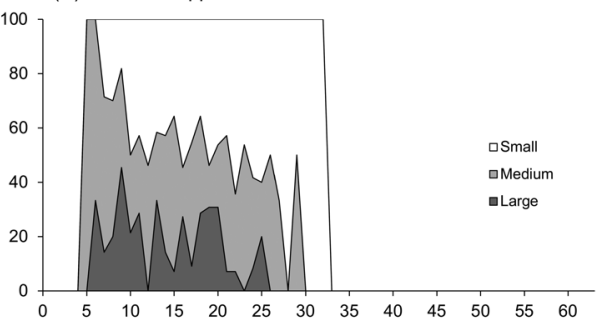

Days after metamorphosis to megalopae

Fig. 4. Changes in the proportions of animals carrying small, medium, and large shells during the sea-to-land transition of Birgus latro under four different salinity levels: 25 (A), 30 (B), 35 (C) and $40 \mathrm{ppt}$ (D). The culture experiments started with 3-day-old animals.

B. latro than in the other species (Fig. 7D).

\section{Discussion}

Our experiments demonstrated that salinity significantly affected the survival and emigra-
(A) C. brevimanus: $25 \mathrm{ppt}$

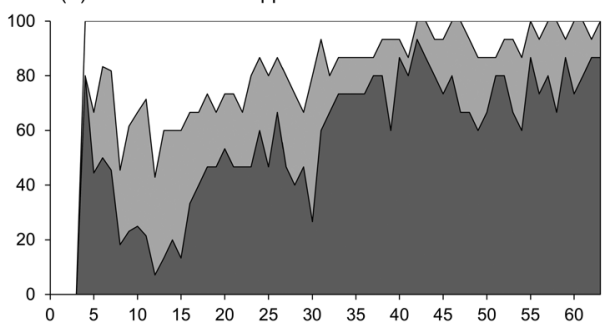

(B) C. brevimanus: $30 \mathrm{ppt}$

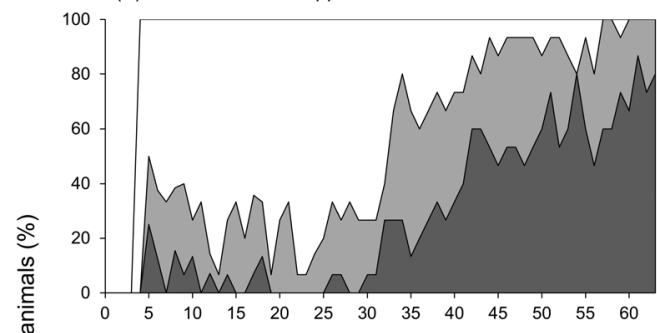

(C) C. brevimanus: $35 \mathrm{ppt}$

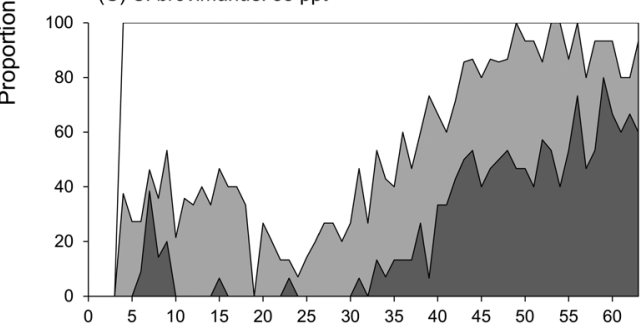

(D) C. brevimanus: $40 \mathrm{ppt}$

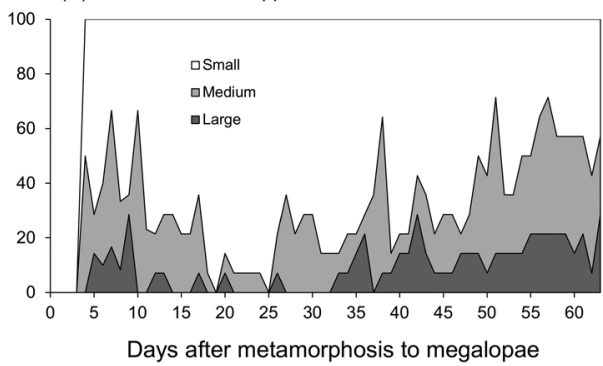

Fig. 5. Changes in the proportions of animals carrying small, medium, and large shells during the sea-to-land transition of Coenobita brevimanus under four different salinity levels: 25 (A), 30 (B), 35 (C) and 40 ppt (D). The culture experiments started with 3-day-old animals.

tion behaviour during the sea-to-land transition of three terrestrial hermit crab species. Overall, survival rates and the proportions of animals engaged in designated behaviour decreased linearly with increasing salinity in coenobitid species (Fig. 7). These results suggest that the en- 
(A) C. purpureus: $25 \mathrm{ppt}$

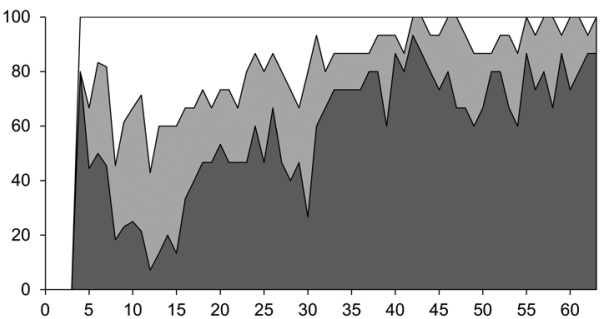

(B) C. purpureus: $30 \mathrm{ppt}$

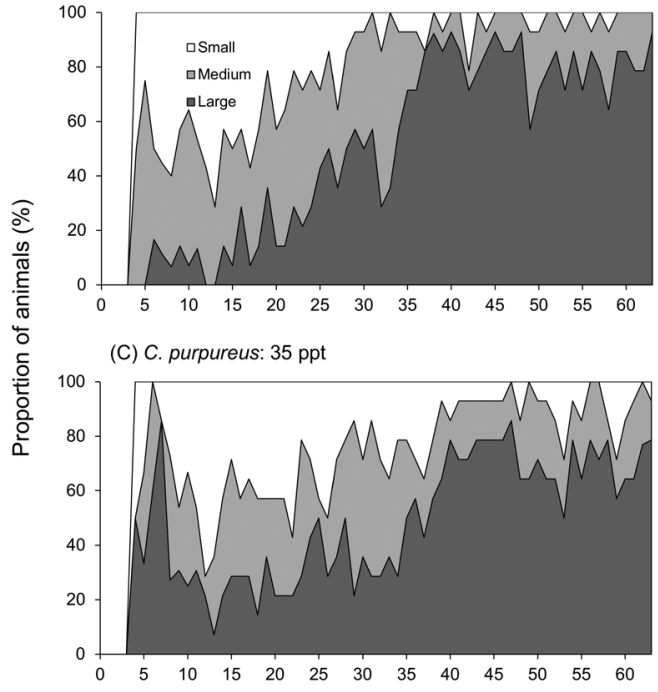

(D) C. purpureus: $40 \mathrm{ppt}$

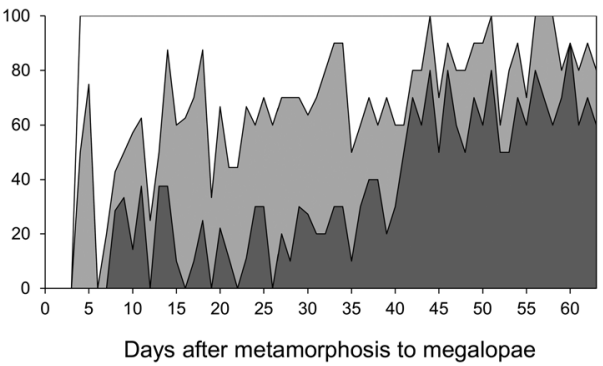

Fig. 6. Changes in the proportions of animals carrying small, medium, and large shells during the sea-to-land transition of Coenobita purpureus under four different salinity levels: 25 (A), 30 (B), 35 (C) and $40 \mathrm{ppt}$ (D). The culture experiments started with 3-day-old animals.

ergetic requirements of these coenobitids may increase for hypo-osmoregulation at higher salinities (Anger, 2001, 2003; Greenaway, 2003), resulting in low survival rates. Wearing a gastropod shell is vital but energetically costly for hermit crabs (Osorno et al., 2005). Terrestrial
(A) Survival

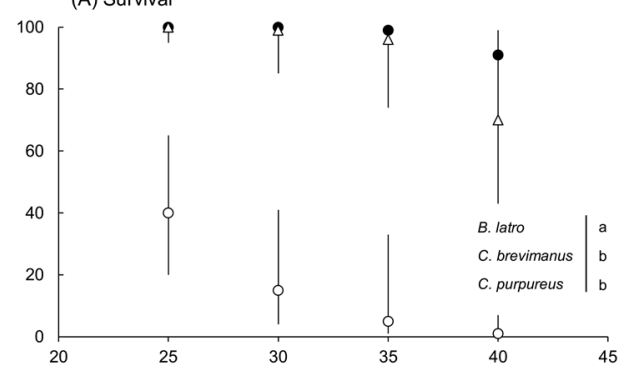

(B) Carrying shells

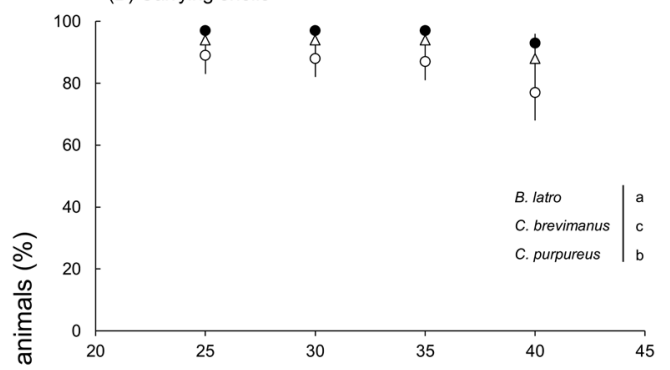

(C) Carrying large shells

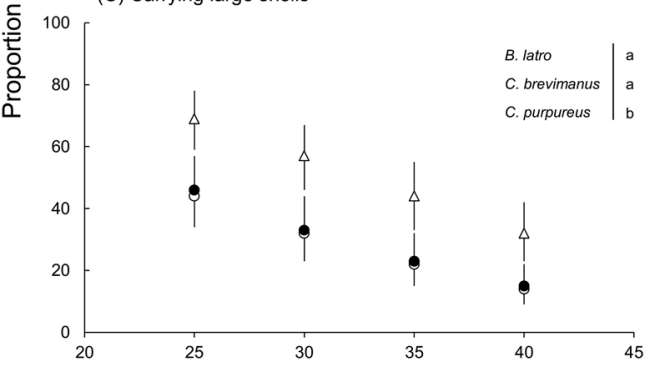

(D) Landing

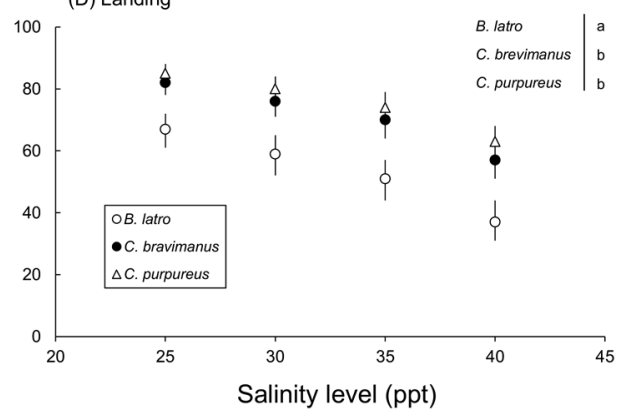

Fig. 7. The predicted values, with $95 \%$ confidence intervals, of the proportions of animals that survived at the end of the experiment (A) and those carrying shells (B), carrying large shells (C) and landing (D) that were derived from the generalised linear model and generalised linear mixedeffects model analyses for each salinity level for each species. Differences in the survival and behavioural traits between the species $(P<0.05)$ are indicated by different lowercase letters in the tables following the species names. 
hermit crab megalopae are expected to expend a high energetic cost to carry shells at sea and to emigrate with them onto land. Therefore, delayed or insufficient shell-carrying and landing behaviours and lower proportions wearing large shells may occur in animals cultured at higher salinity levels (Figs. 1-7).

Hamasaki et al. (2014b, 2015b) examined the survival, moulting and emigration behaviour during the sea-to-land transition of six terrestrial hermit crab species-B. latro, $C$. brevimanus, C. cavipes, C. purpureus, C. rugosus and $C$. violascens-using similar culture containers as employed in the present study (salinity $34 \mathrm{ppt}$, temperature $27-28^{\circ} \mathrm{C}$, and relative humidity $80-90 \%$ ) for 60 days after metamorphosis to the megalopal stage. Fujikawa et al. (2018) also examined these traits of $C$. rugosus and $C$. violascens under two different salinity conditions (24 and $34 \mathrm{ppt)}$ (temperature $28^{\circ} \mathrm{C}$ and relative humidity $86 \%$ ) for 44 days. They reported that the animals moulted to the second or third crab stages. In the present study, we did not monitor the moulting of animals, but our observations should evaluate the survival and behaviour from megalopae to early juveniles, according to these previous studies. Fujikawa et al. (2018) also documented the similar behavioural responses to salinity by megalopae and early juveniles of $C$. rugosus and $C$. violascens as in the present study. In that study, reduced salinity (24 ppt) stimulated shell-wearing activity and/or landing activity and enhanced the moulting and survival of the animals.

Our experiments also demonstrated the distinct interspecific variability in the salinity adaptation of megalopae and early juvenile coenobitid crabs (Fig. 7), indicating that osmoregulatory capacity differs among coenobitids. C. brevimanus and C. purpureus showed relatively high survival rates even at higher salinity levels compared with B. latro. Thus, the hypoosmoregulatory ability may be stronger in C. brevimanus and C. purpureus than in

\section{B. latro.}

Early juveniles of C. purpureus inhabit sandy beach conditions (Hamasaki et al., 2018; Sanda et al., 2018a, 2018b; Inutsuka et al., 2020) with high ground temperatures (Hamasaki et al., 2018) that may induce overheating and desiccation, thereby leading to hypersaline environments. Megalopae and early juveniles of C. purpureus might have evolved the strong hypo-osmoregulatory ability to adapt to the high-temperature niche. On the other hand, C. brevimanus is a primarily coastal forest dweller; however, the main habitats of early juveniles of this species remain largely unknown because few early juveniles have been collected in the wild (Hamasaki et al., 2018). Our results suggest that the early juveniles of C. brevimanus may adapt to a niche similar to that of $C$. purpureus. Future field studies are required to elucidate the habitats of early juveniles of $C$. brevimanus.

$B$. latro inhabits the limestone shore and inland area (Fujikawa et al., 2017; Hamasaki et al., 2018; Tsuru et al., 2018), while megalopae and early juveniles of $B$. latro carrying shells prefer environments with high humidity. Laboratory-raised megalopae of $B$. latro show a strong preference for coral fragments for settlement (Hamasaki et al., 2015c), and they gather under shelters, such as coral rubble, after migrating onto land (Hamasaki et al., 2011). The cryptic habits of $B$. latro megalopae and early juveniles with shells make it difficult to locate them in natural habitats, and we never found them in our field surveys (Hamasaki et al., 2018). On a few occasions, these cryptic animals were found under piles of coconuts or in coral rubble (Kadiri-Jan \& Chauvet, 1998; Fujita \& Ito, 2008; Drew et al., 2010). Megalopae and early juveniles of $B$. latro may adapt to the high humidity environment under the debris, thereby reducing their hypo-osmoregulatory ability.

Early megalopae tended to acquire medium or large shells in all coenobitid species (Figs. 
4-6). Hamasaki et al. (2014a) analysed the relationship between body size and shell size occupied by the laboratory-raised juveniles of $B$. latro and suggested that smaller juveniles may use relatively larger shells because the shells that best fit the animal body sizes may limit the growth of smaller juveniles with shorter moulting intervals, i.e. higher moulting frequency. The proportions of animals carrying medium or large shells once decreased during the first landing phase in all species probably because they expended a high energetic cost to emigrate with them onto land. Animals then changed their preference for shells from the small to large size according to age (i.e. growth) (Figs. 4-6) as previously demonstrated for megalopae and early juveniles of coenobitid crabs (Hamasaki et al., 2014a, 2015b).

Furthermore, interspecific variability was evident in shell size preference, and C. purpureus preferred large shells compared with the other species (Fig. 7D). This can be explained by the body size differences among coenobitid megalopae. Hamasaki et al. (2015b) detected a significant negative correlation between megalopal body size and the number of days when megalopae wore a small-sized shell during the sea-to-land transition of six coenobitids under laboratory experiments, and megalopae of $C$. purpureus were larger than those of C. brevimanus and B. latro.

Our laboratory experiments highlight the interspecific variability in performance of megalopae and early juveniles during the sea-to-land transition of three terrestrial hermit crab species under different salinity conditions. Our results suggest that $25 \mathrm{ppt}$ salinity is an appropriate condition for culturing megalopae and early juveniles of these coenobitids. To further elucidate the salinity adaptation of megalopae and early juveniles of coenobitid crabs, survival and emigration behaviour as well as osmoregulatory capacity should be investigated under a broader range of salinity levels in future studies.

\section{Acknowledgements}

We would like to acknowledge the Okinawa Prefectural Board of Education and the Agency for Culture Affairs, Ministry of Education, Culture, Sports, Science and Technology of Japan, for permission to collect the land hermit crabs. We are grateful to the anonymous reviewers and the editor for their valuable comments and suggestions, which have improved the manuscript. This study was supported by JSPS KAKENHI grant number JP24310171 to $\mathrm{KH}$.

\section{Literature Cited}

Anger, K., 2001. The Biology of Decapod Crustacean Larvae. Crustacean Issues, vol. 14. 419 pp. A.A. Balkema, Lisse.

Anger, K., 2003. Salinity as a key parameter in the larval biology of decapod crustaceans. Invertebrate Reproduction \& Development, 43: 29-45.

Amesbury, S. S., 1980. Biological studies on the coconut crab (Birgus latro) in the Mariana Islands. University of Guam Marine Laboratory Technical Report, 66: 1-39.

Bates, D., Maechler, M., Bolker, B., \& Walker, S., 2015. Fitting linear mixed-effects models using lme4. Journal of Statistical Software, 67: $1-48$

Brodie, R. J., 1999. Ontogeny of shell-related behaviors and transition to land in the terrestrial hermit crab Coenobita compressus H. Milne Edwards. Journal of Experimental Marine Biology and Ecology, 241: 67-80.

Brown, I. W., \& Fielder. D. R., 1991. Project overview and literature survey. In: I. W. Brown, \& D. R. Fielder, (eds.), The Coconut Crab: Aspects of Birgus latro Biology and Ecology in Vanuatu. ACIAR Monograph No. 8. Australian Centre for International Agricultural Research, Canberra, ACT, pp. $1-11$.

Drew, M. M., Harzsch, S., Stensmyr, M., Erland, S., \& Hansson, B. S., 2010. A review of the 
biology and ecology of the robber crab, Birgus latro (Linnaeus, 1767) (Anomura: Coenobitidae). Zoologischer Anzeiger, 249: 45-67.

Fox, J., \& Weisberg, S., 2011. An R Companion to Applied Regression. 2nd Edition. 472 pp. Sage Publications, Thousand Oaks, CA.

Fujikawa, S. Hamasaki, K., Sanda, T., Ishiyama, N., Tsuru, T., Dan, S., \& Kitada, S., 2017. Distributional characteristics of terrestrial hermit crabs along the coasts of Ishigakijima Island and Iriomotejima Island, Ryukyu Archipelago, Japan. Bulletin of the Biogeographical Society of Japan, 71: 25-38. (In Japanese with English abstract)

Fujikawa, S. Hamasaki, K., Dan, S., \& Kitada, S., 2018. Emigration behaviour, moulting and survival during the sea-to-land transition of land hermit crabs Coenobita violascens and Coenobita rugosus under laboratory conditions: effects of salinity and riverine odours. Biogeography, 20: 111-121.

Fujita, Y., \& Ito, A., 2008. Notes on the behavior of shell carrying coconut crab, Birgus latro (Linnaeus, 1758), reared in the laboratory. Cancer, 17: 1-4. (In Japanese)

Greenaway, P., 2003. Terrestrial adaptations in the Anomura (Crustacea: Decapoda). Memoirs of Museum Victoria, 60: 13-26.

Hamasaki, K., 2011. Early life history of coconut crabs inferred from culture experiments. Cancer, 20: 73-77. (In Japanese)

Hamasaki, K., Sugizaki, M., Dan, S., \& Kitada, S., 2009. Effect of temperature on survival and developmental period of coconut crab (Birgus latro) larvae reared in the laboratory. Aquaculture, 292: 259-263.

Hamasaki, K., Sugizaki, M., Sugimoto, A., Murakami, Y., \& Kitada, S., 2011. Emigration behaviour during sea-to-land transition of the coconut crab Birgus latro: effects of gastropod shells, substrata, shelters and humidity. Journal of Experimental Marine Biology and Ecology, 403: 81-89.

Hamasaki, K., Yamashita, S., Ishiyama, N., \& Kitada, S., 2013. Effects of water availability and migration timing from sea to land on survival and moulting in megalopae and juveniles of the coconut crab, Birgus latro: implications for mass production of juveniles. Journal of Crustacean Biology, 33: 627-632.

Hamasaki, K., Ishiyama, N., Yamashita, S., \& Kitada, S., 2014a. Survival and growth of juveniles of the coconut crab Birgus latro under laboratory conditions: implications for mass production of juveniles. Journal of Crustacean Biology, 34: 309-318.

Hamasaki, K., Kato, S., Hatta, S., Murakami, Y., Dan, S., \& Kitada, S., 2014b. Larval development and emigration behaviour during sea-to-land transition of the land hermit crab Coenobita brevimanus Dana, 1852 (Crustacea: Decapoda: Anomura: Coenobitidae) under laboratory conditions. Journal of Natural History, 48: 1061-1084.

Hamasaki, K., Kato, S., Murakami, Y., Dan, S., \& Kitada, S., 2015a. Larval growth, development and duration in terrestrial hermit crabs. Sexuality and Early Development in Aquatic Organisms, 1: 93-107.

Hamasaki, K., Hatta, S., Ishikawa, T., Yamashita, S., Dan, S., \& Kitada, S., 2015b. Emigration behaviour and moulting during the sea-toland transition of terrestrial hermit crabs under laboratory conditions. Invertebrate Biology, 134: 318-331.

Hamasaki, K., Ishiyama, N., \& Kitada, S., 2015c. Settlement behavior and substrate preference of the coconut crab Birgus latro megalopae on natural substrata in the laboratory. Journal of Experimental Marine Biology and Ecology, 468: 21-28.

Hamasaki, K., Fujikawa, S., Iizuka, C., Sanda, T., Tsuru, T., Imai, H., \& Kitada, S., 2018. Recruitment to adult habitats in terrestrial hermit crabs on the coast of Ishigakijima Island, Ryukyu Archipelago, Japan. Invertebrate Biology, 137: 3-16.

Hamasaki, K., Saito, Y., Ogiso, Y., Fujie, Y., Tabata, K., Dan, S., \& Kitada, S., 2020. Effect of temperature on larval survival, de- 
velopment and duration of six terrestrial hermit crab species under laboratory conditions. Aquatic Animals, AA2020: AA2020-6.

Hartnoll, R. G., 1988. Evolution, systematic, and geographical distribution. In: W. W. Burggren, \& B. R. McMahon, (eds.), Biology of the Land Crabs, Cambridge University Press, New York, NY, pp. 6-54.

Harvey, A. W., 1992. Abbreviated larval development in the Australian terrestrial hermit crab Coenobita variabilis McCulloch (Anomura: Coenobitidae). Journal of Crustacean Biology, 12: 196-209.

Hothorn, T., Bentz, F., \& Westfall, P., 2008. Simultaneous inference in general parametric models. Biometrical Journal, 50: 346-363.

Hydrographic and Oceanographic Department, 2021. https://www1.kaiho.mlit.go.jp/KAN11/ atlas/sal/sal0-sm.gif. (Accessed 26 July 2021).

Inutsuka. S., Hamasaki, K., Dan, S., \& Kitada, S., 2020. Occurrence and distribution of early juvenile land hermit crabs at a small beach on the Boso Peninsula, Japan. Nauplius, 28: e2020002.

Kadiri-Jan, T., \& Chauvet, C., 1998. Distribution of the juvenile coconut crab, Birgus latro (L.), on the island of Lifou, New Caledonia. Ecoscience, 5: 275-278.

Kawachi, A., \& Ishikawa, T., 2008. Effect of water flow on megalopal settlement in Nagura Amparu tidal lagoon, Ishigaki Island, Okinawa. Kaigan Kogaku Ronbunshu, 55: 1151-1155. (In Japanese with English abstract)

Kawachi, A., Ishikawa, T., \& Kikuchi, H., 2009. Recruitment process of brachyuran megalopa in the Amparu tidal lagoon, Ishigaki Island, Okinawa, Japan. Journal of Japan Society of Civil Engineers, Series B2 (Coastal Engineering), B2-65: 1106-1110. (In Japanese with English abstract)

McLaughlin, P. A., Komai, T., Lemaitre, R., \& Rahayu, D. L., 2010. Annotated checklist of anomuran decapod crustaceans of the world (exclusive of the Kiwaoidea and families
Chirostylidae and Galatheidae of the Galatheoidea) Part I-Lithodoidea, Lomisoidea and Paguroidea. The Raffles Bulletin of Zoology, Supplement, 23: 5-107.

Nakasone, Y., 2001. Reproductive biology of three land hermit crabs (Decapoda: Anomura: Coenobitidae) in Okinawa, Japan. Pacific Science, 55: 157-169.

Osorno, J. L., Contreras-Garduño, J., \& MacíasGarcia, C., 2005. Long-term costs of using heavy shells in terrestrial hermit crabs (Coenobita compressus) and the limits of shell preference: an experimental study. Journal of Zoology, 266: 377-383.

Pavia, A., 2006. Hermit Crab: Your Happy Healthy Pet. 127 pp. Wiley Publishing Inc., Hoboken, NJ.

Poupin, J., 1996. Crustacea Decapoda of French Polynesia (Astacidea, Palinuridea, Anomura, Brachyura). Atoll Research Bulletin, 442: $1-114$.

R Core Team, 2021. R: A Language and Environment for Statistical Computing. R Foundation for Statistical Computing, Vienna, Austria. https://www.R-project.org/ (Accessed 10 August 2021).

Rahayu, D. L., Shihm, H.-T., \& Ng, P. K. L., 2016. A new species of land hermit crab in the genus Coenobita Latreille, 1829 from Singapore, Malaysia and Indonesia, previously confused with $C$. cavipes Stimpson, 1858 (Crustacea: Decapoda: Anomura: Coenobitidae). The Raffles Bulletin of Zoology, Supplement, 34: 470-488.

Reese, E. S., 1968. Shell use: an adaptation for emigration from the sea by the coconut crab. Science, 161: 385-386.

Sanda, T., Iizuka, C., Hamasaki, K., \& Kitada, S., 2018a. Distribution of terrestrial hermit crabs on the coasts of Chichijima Island in the Bonin Islands and Hachijojima Island in the Izu Islands, Japan. Bulletin of the Biogeographical Society of Japan, 72: 65-74. (In Japanese with English abstract)

Sanda, T., Hamasaki, K., \& Kitada, S., 2018 b. Distribution of terrestrial hermit crabs on the 
coasts of Takarajima Island, Kagoshima Prefecture, and Otsuki-cho, Kochi Prefecture, Japan. Bulletin of the Biogeographical Society of Japan, 73: 87-94. (In Japanese with English abstract)

Tottori, K., Nagao, M., Morimoto, N., Inoue, M., Iwase, A., Shibuno, T., Fujioka, Y., Ohba, H., Kan, H., \& Suzuki, A., 2004. Relationship between sediments and water turbidity in coral reefs around Ishigaki Island, the Ryukyus. Galaxea, 6: 1-19. (In Japanese with English abstract)

Tsuru, T., Hamasaki, K., Sanda, T., Fujikawa, S., $\&$ Kitada, S., 2018. Distribution of terrestrial hermit crabs on Hatomajima Island, Ryukyu Archipelago, Japan. Bulletin of the Biogeographical Society of Japan, 72: 75-85. (In
Japanese with English abstract)

Zuur, A. F., Ieno, E. N., Walker, N. J., Saveliev, A. A., \& Smith, G. M., 2009. Mixed Effects Models and Extensions in Ecology with R. 574 pp. Springer, New York, NY.

\section{Addresses}

(TW) (KH) (SD) (SK) Department of Marine Biosciences, Tokyo University of Marine Science and Technology, Konan, Minato, Tokyo 108-8477, Japan

\section{E-mail address of corresponding author}

(KH)hamak@kaiyodai.ac.jp 